\title{
Responding to Late Blight Disease Pressure and Fungicide Resistance Using Multiple Fungicide Active Ingredients and Different Spraying Regimes in Uganda
}

\author{
Arinaitwe Abel Byarugaba ${ }^{1,3,}$, Mateeka Benon ${ }^{1}$, Tibanyedera Deo², Barekye Alex ${ }^{1}$ \\ ${ }^{1}$ Kachwekano Zonal Agricultural Research and Development Institute, Kabale, Uganda \\ ${ }^{2}$ International Fertilizer Development Centre (IFDC), Kampala, Uganda \\ ${ }^{3}$ Faculty of Interdisciplinary Studies (FIS), Mbarara University of Science and Technology, Mbarara, Uganda
}

Email address:

abelarinaitwe@gmail.com (A. A. Byarugaba)

${ }^{*}$ Corresponding author

\section{To cite this article:}

Arinaitwe Abel Byarugaba, Mateeka Benon, Tibanyedera Deo, Barekye Alex. Responding to Late Blight Disease Pressure and Fungicide Resistance Using Multiple Fungicide Active Ingredients and Different Spraying Regimes in Uganda. Agriculture, Forestry and Fisheries. Vol. 7, No. 3, 2018, pp. 82-88. doi: 10.11648/j.aff.20180703.13

Received: February 16, 2018; Accepted: March 29, 2018; Published: September 26, 2018

\begin{abstract}
Late blight (Phytophthora infestans) is one of the major diseases of economic importance limiting potato production in Uganda and causing yield losses of $40-60 \%$. The emergence of more aggressive late blight pathotypes that are more difficult to control with ability to overcome host resistance or resist fungicide active ingredients has been noted in Uganda. Therefore, this study was carried out to identify suitable fungicides and spray regime for the effective management of late blight pathotypes on susceptible potato varieties in Uganda. Different fungicides that known to control late blight include Consento (Fenamidone 6.7\% w/w + Propamacarb hydrochroride 93.6\% w/w), Infinito (Propamacarb $(55.3 \% \mathrm{w} / \mathrm{w}+$ Fluopicollide (5.53\% w/w), Mancozeb (Dithiocarbamate 800g/kg), Agrolaxzyl (Metalaxyl $80 \mathrm{~g} / \mathrm{kg}+$ Mancozeb $640 \mathrm{~g} / \mathrm{kg}$ WP) were acquired from Bayer Crop Sciences and agro-inputs dealers in Uganda and tested for effective management of late blight on susceptible potato varieties in four different sites for two seasons (2015B and 2016A) using randomized complete block design (RCBD). Three (3) spraying regimes were tested and included; Bayer Crop Sciences recommended spray regime, current Uganda's recommended spray regime, Hybrid (blend of Uganda's recommended spray regime and Bayer recommendation) and no spray as control. Data on late blight disease severity was measured as percentage plant area affected (PLAA) and this was converted in to area under disease progress curve (AUDPC). The results showed that area under disease progress curve (AUDPC) ranged from 357-763 for the 3 different spray regimes while for the control (No spray), it ranged from 1895-2231. The late blight disease severity varied across sites and seasons, with Kalegyere site recording highest disease pressure in season 1 while Buginyanya had highest disease severity in season 2. Lowest disease pressure was registered with Bayer Crop Sciences based spray regime in season 1, while in season 2, hybrid spray regime registered lowest disease pressure. Use of multiple fungicide ingredients (Mancozeb (Dithiocarbamate $800 \mathrm{~g} / \mathrm{kg}$ ), Consento (Fenamidone 6.7\% w/w + Propamacarb hydrochroride 93.6\% w/w); Infinito (Propamacarb $55.3 \% \mathrm{w} / \mathrm{w}+$ Fluopicollide $(5.53 \% \mathrm{w} / \mathrm{w})$ and Agrolaxzyl (Metalaxyl $80 \mathrm{~g} / \mathrm{kg}$ + Mancozeb $640 \mathrm{~g} / \mathrm{kg} \mathrm{WP}$ ) at different intervals has demonstrated the potential to suppress the disease to levels not causing serious economic damages by not allowing significant disease development on the leaves, hence has been recommended to be used for the management of late blight in Uganda.
\end{abstract}

Keywords: Late Blight, Spray Regimes, Disease Pressure, Fungicide, Disease Management 


\section{Introduction}

Late blight (Phytophthora infestans (Mont.) de Bary is one of the major diseases of economic importance to potato production in Uganda and elsewhere in Sub-Saharan Africa [6]. World-wide losses due to late blight exceed several billion dollars annually [7]. In Uganda, the disease causes 40-60\% [2]. This loss in production translates at average cost of 700 UGX per $\mathrm{kg}$ of potato to over 129 million dollars. The disease attacks leaves, stems and tubers and studies have shown that potato tubers stop growing when $75 \%$ of the plant canopy has been destroyed by blight [13]. There is an increasing pressure of Late blight disease on potatoes and this, is coupled with emergence of more aggressive late blight pathotypes that are more difficult to control with ability to overcome host resistance or resist fungicide active ingredients. The dominant late blight strain in Uganda in the past has been A1 mating type colonal lineage US-1 which has been displaced by a more virulent strain KE-1 [12]. This late blight pathogen population is noted to have high ability to change and evolve as evidenced by change in behavior of the newer populations of $P$. infestans which seem to vary geographically 5 .

Most farmers in Uganda manage the late blight disease by spraying using fungicides $[9,11]$. A number of potato varieties are very susceptible to late blight pathotypes and their production largely depends on fungicide application. Therefore this study was conducted to evaluate the different fungicide active ingredients and spray regimes that could be used to effectively manage the increasing late blight disease pressure on susceptible potato varieties in Uganda.

\section{Materials and Methods}

\subsection{Effectiveness of Different Fungicides and Spray Regimes on Management of Late Blight Disease}

Four late blight susceptible varieties were used in the study and these comprised of 3 Dutch potato varieties ('El-Mundo', 'Markies' and 'Sagitta') and local late blight susceptible check 'Victoria'. The varieties were planted in a randomized complete block design (RCBD) with two replicates at Kalegyere (2450m/asl), Kachwekano (2225m/asl), Rwebitaba (1531m/asl) and Buginyanya $(1887 \mathrm{~m} / \mathrm{asl})$ at a spacing of $75 \times 30 \mathrm{~cm}$ with each plot separated by $1 \mathrm{~m}$ distance. The experimental design was arranged in split-split-plots replicated 2 times. The main plots were fungicide spray regime; sub-plots were cultivars. The trials were established at these four sites because of high disease pressure of late blight in these areas in 2015B and 2016A seasons. The experimental treatment comprised of different potato varieties and fungicides that were applied based on 3 spray regimes (Bayer Crop Sciences recommended spray regime, current Uganda's recommended spray regime, Hybrid (blend of Uganda's recommended spray regime and Bayer recommendation) and no spray as control. (Table 1). The experimental trial was infected naturally under field conditions. The plants were monitored on weekly basis for late blight development and disease severity data was recorded as percentage leaf area affected due to the late blight disease following fungicide application [4].

\subsection{Data Collection}

Data on late blight disease severity was scored weekly starting at 30 days after planting using a scale developed by Landeo and Forbes [10] modified from Henfling [8]. Data was collected starting from when traces of Late blight were observed and continuing until physiological maturity. Disease severity data measured as percentage plant leaf area affected (PLAA) was then used to compute Area under disease progress curve (AUDPC) using procedure of Campbell and Madane [3]. Upon harvesting, yield data was also collected under different spray regimes and tubers were categorized into 3 groups; $1=$ small tubers $(<30 \mathrm{~mm}), 2=$ medium $(45-60 \mathrm{~mm})$ and $3=$ large $(>60 \mathrm{~mm})$.

Statistical methods. Analysis of variance was performed on the AUDPC values of potato varieties for the study; the percent foliar late blight infection values for each field study evaluations using Genstart computer package 11 edition. Mean comparisons were conducted using Fisher's Least Significant Difference (LSD $=0.05$ ). The sources of variability used in the statistical model were treatment (variety), Spray regime, the blocks (replicates) and the experimental error.

Table 1. Different fungicides and their spraying regimes for the management of late blight disease on potatoes in Uganda.

\begin{tabular}{|c|c|c|c|c|c|}
\hline & $1^{\text {ST }}$ WEEK & $2^{\mathrm{ND}}$ WEEK & $3^{\mathrm{RD}}$ WEEK & $4^{\mathrm{TH}}$ WEEK & $5^{\text {TH }}$ WEEK \\
\hline $\begin{array}{l}\text { Bayer Crop Sciences } \\
\text { recommended spray } \\
\text { regime, }\end{array}$ & $\begin{array}{l}\text { 30ml Consento } \\
\text { (Fenamidone } 6.7 \% \mathrm{w} / \mathrm{w}+ \\
\text { Propamacarb } \\
\text { hydrochroride } 93.6 \% \mathrm{w} / \mathrm{w} \text { ) } \\
/ 15 \text { litres of water }\end{array}$ & & $\begin{array}{l}\text { 30ml Consento } \\
\text { (Fenamidone } 6.7 \% \mathrm{w} / \mathrm{w} \\
+ \text { Propamacarb } \\
\text { hydrochroride } 93.6 \% \\
\text { w/w) } / 15 \text { litres of water }\end{array}$ & & $\begin{array}{l}30 \mathrm{ml} \text { Consento } \\
\text { (Fenamidone } 6.7 \% \mathrm{w} / \mathrm{w}+ \\
\text { Propamacarb } \\
\text { hydrochroride } 93.6 \% \mathrm{w} / \mathrm{w} \text { ) } \\
/ 15 \text { litres of water }\end{array}$ \\
\hline $\begin{array}{l}\text { Current Uganda's } \\
\text { recommended spray } \\
\text { regime, }\end{array}$ & $\begin{array}{l}50 \mathrm{~g} \text { of Mancozeb } \\
\text { (Dithiocarbamate } 800 \mathrm{~g} / \mathrm{kg} \text { ) } \\
/ 15 \text { litres of water) }\end{array}$ & $\begin{array}{l}50 \mathrm{~g} \text { of Mancozeb } \\
\text { (Dithiocarbamate } \\
800 \mathrm{~g} / \mathrm{kg} \text { ) } / 15 \text { litres } \\
\text { of water) }\end{array}$ & $\begin{array}{l}50 \mathrm{~g} \text { of Agrolaxzyl } \\
\text { (Metalaxyl } 80 \mathrm{~g} / \mathrm{kg}+ \\
\text { Mancozeb } 640 \mathrm{~g} / \mathrm{kg} \\
\text { WP) } / 15 \text { litres of water }\end{array}$ & & $\begin{array}{l}50 \mathrm{~g} \text { of Mancozeb } \\
\text { (Dithiocarbamate } 800 \mathrm{~g} / \mathrm{kg} \text { ) } \\
/ 15 \text { litres of water) }\end{array}$ \\
\hline $\begin{array}{l}\text { Hybrid (blend of } \\
\text { Uganda's recommended } \\
\text { spray regime and Bayer } \\
\text { recommendation) }\end{array}$ & $\begin{array}{l}50 \mathrm{~g} \text { of Mancozeb } \\
\text { (Dithiocarbamate } 800 \mathrm{~g} / \mathrm{kg} \text { ) } \\
/ 15 \text { litres of water) }\end{array}$ & $\begin{array}{l}50 \mathrm{~g} \text { of Mancozeb } \\
\text { (Dithiocarbamate } \\
800 \mathrm{~g} / \mathrm{kg} \text { ) } / 15 \text { litres } \\
\text { of water) }\end{array}$ & $\begin{array}{l}30 \mathrm{ml} \text { Consento } \\
\text { (Fenamidone } 6.7 \% \mathrm{w} / \mathrm{w} \\
\text { + Propamacarb } \\
\text { hydrochroride } 93.6 \% \\
\text { w/w) } / 15 \text { litres of water }\end{array}$ & & $\begin{array}{l}50 \mathrm{~g} \text { of Mancozeb } \\
\text { (Dithiocarbamate } 800 \mathrm{~g} / \mathrm{kg} \text { ) } \\
/ 15 \text { litres of water) }\end{array}$ \\
\hline Control (No spray) & No spray & No spray & No spray & No spray & No spray \\
\hline
\end{tabular}


Table 1. Continued.

\begin{tabular}{|c|c|c|c|c|c|c|}
\hline & $6^{\mathrm{TH}}$ WEEK & $7^{\mathrm{TH}}$ WEEK & $8^{\mathrm{TH}}$ WEEK & $9^{\mathrm{TH}}$ WEEK & $10^{\mathrm{TH}}$ WEEK & 11 ${ }^{\mathrm{TH}}$ WEEK \\
\hline $\begin{array}{l}\text { Bayer Crop } \\
\text { Sciences } \\
\text { recommended spray } \\
\text { regime, }\end{array}$ & & $\begin{array}{l}27 \mathrm{ml} \text { of Infinito } \\
\text { (Propamacarb } \\
(55.3 \% \mathrm{w} / \mathrm{w}+ \\
\text { Fluopicollide } \\
(5.53 \% \mathrm{w} / \mathrm{w}) / 15 \\
\text { mls of water }\end{array}$ & & $\begin{array}{l}27 \mathrm{ml} \text { of Infinito } \\
\text { (Propamacarb } \\
(55.3 \% \mathrm{w} / \mathrm{w}+ \\
\text { Fluopicollide } \\
(5.53 \% \mathrm{w} / \mathrm{w}) / 15 \\
\mathrm{mls} \text { of water }\end{array}$ & & $\begin{array}{l}27 \mathrm{ml} \text { of Infinito } \\
\text { (Propamacarb }(55.3 \% \\
\mathrm{w} / \mathrm{w}+\text { Fluopicollide } \\
(5.53 \% \mathrm{w} / \mathrm{w}) / 15 \mathrm{mls} \\
\text { of water }\end{array}$ \\
\hline $\begin{array}{l}\text { Current Uganda's } \\
\text { recommended spray } \\
\text { regime, }\end{array}$ & $\begin{array}{l}50 \mathrm{~g} \text { of Agrolaxzyl } \\
\text { (Metalaxyl } 80 \\
\mathrm{~g} / \mathrm{kg}+\text { Mancozeb } \\
640 \mathrm{~g} / \mathrm{kg} \mathrm{WP}) / 15 \\
\text { litres of water }\end{array}$ & $\begin{array}{l}50 \mathrm{~g} \text { of Mancozeb } \\
\text { (Dithiocarbamate } \\
800 \mathrm{~g} / \mathrm{kg} \text { ) } / 15 \text { litres } \\
\text { of water) }\end{array}$ & & $\begin{array}{l}50 \mathrm{~g} \text { of Mancozeb } \\
\text { (Dithiocarbamate } \\
800 \mathrm{~g} / \mathrm{kg} \text { ) } / 15 \text { litres } \\
\text { of water) }\end{array}$ & & \\
\hline $\begin{array}{l}\text { Hybrid (blend of } \\
\text { Uganda's } \\
\text { recommended spray } \\
\text { regime and Bayer } \\
\text { recommendation) }\end{array}$ & $\begin{array}{l}27 \mathrm{ml} \text { of Infinito } \\
\text { (Propamacarb } \\
(55.3 \% \mathrm{w} / \mathrm{w}+ \\
\text { Fluopicollide } \\
(5.53 \% \mathrm{w} / \mathrm{w}) / 15 \\
\text { mls of water }\end{array}$ & $\begin{array}{l}50 \mathrm{~g} \text { of Mancozeb } \\
\text { (Dithiocarbamate } \\
800 \mathrm{~g} / \mathrm{kg} \text { ) } / 15 \text { litres } \\
\text { of water) }\end{array}$ & $\begin{array}{l}50 \mathrm{~g} \text { of } \\
\text { Agrolaxzyl } \\
(\text { Metalaxyl } 80 \\
\mathrm{g} / \mathrm{kg}+\text { Mancozeb } \\
640 \mathrm{~g} / \mathrm{kg} \mathrm{WP}) / 15 \\
\text { litres of water }\end{array}$ & & & \\
\hline Control (No spray) & No spray & No spray & No spray & No spray & No spray & No spray \\
\hline
\end{tabular}

\section{Results}

Effectiveness of Different Fungicide Active Ingredient and Spray Regimes on Management of Late Blight Disease Pressure on Susceptible Potato Varieties

Following application of different fungicides, the results of the study indicated a significant difference $(\mathrm{P}<0.005)$ in severity of potato varieties in response to late blight infection. The study showed that amount of late blight disease on each of the varieties varied from 357-763 under different spray regime while where no fungicide was applied, the amount of disease was high (1895-2231) (Table 2). Variety El-mundo and Sagitta had higher disease severities compared to Markies and Victoria under different spray regimes. The proportion of the amount of disease in the field in comparison with control check was lower for Bayer crop sciences recommended fungicide spray regime (22.6\%), followed by Hybrid spray regime (25.2\%), current Uganda's recommended fungicide spray regime (35.1\%). Disease severity was higher in season 2 than in season 1 (Figure 1 and Figure 2). This was mainly attributed to high disease pressure during the season 2 and stable rainfall and moderately lower temperatures during growing season that favored higher disease development. Season 1 was mainly characterized by higher temperatures and low rains which did not favor the build up the disease during the evaluation period (Weather data not shown). The highest plant area affected was noted to be $67 \%$ severity for no spray in season 1 while in season 2 was $85 \%$. Bayer crop sciences recommended fungicide spray regime was more effective in season 1 while hybrid regime was more effective in season 2. In terms of late blight disease control options, there was no significant difference between Bayer crop sciences recommended fungicide spray and hybrid. regime, however these two were significantly different from current Uganda's recommended spray regime neither of the spray regime was able to suppress the disease completely but were able to reduce the effects of disease on the foliage to levels that do not significantly affect yield. The average yield for the 3 spray regime ranged from 18.4-18.9 T/ha which was $65 \%$ higher than the control (No spray) (Table 3). Variety Markies and El-mundo performed relatively better than Victoria and Sagitta under the 3 spray regime with average marketable yield of 19-21 T/ha. The use of different fungicide active ingredient under hybrid spray regime is hence recommended for management of late blight as this would reduce on development of resistance to fungicide. This is in agreement with Brent and Hollomon [1] assertion that resistance to fungicides can be effectively managed using different active ingredients to minimize sudden and marked loss of effectiveness. Use of multiple fungicide ingredients (Hybrid spray regime) at different intervals has demonstrated the potential to suppress the disease to levels not causing serious economic damages by not allowing significant disease development on the leaves. This strategy would also minimize the chances of disease carryover to the tubers hence ensuring higher quality of tubers as well as minimizing development of resistance to fungicides 


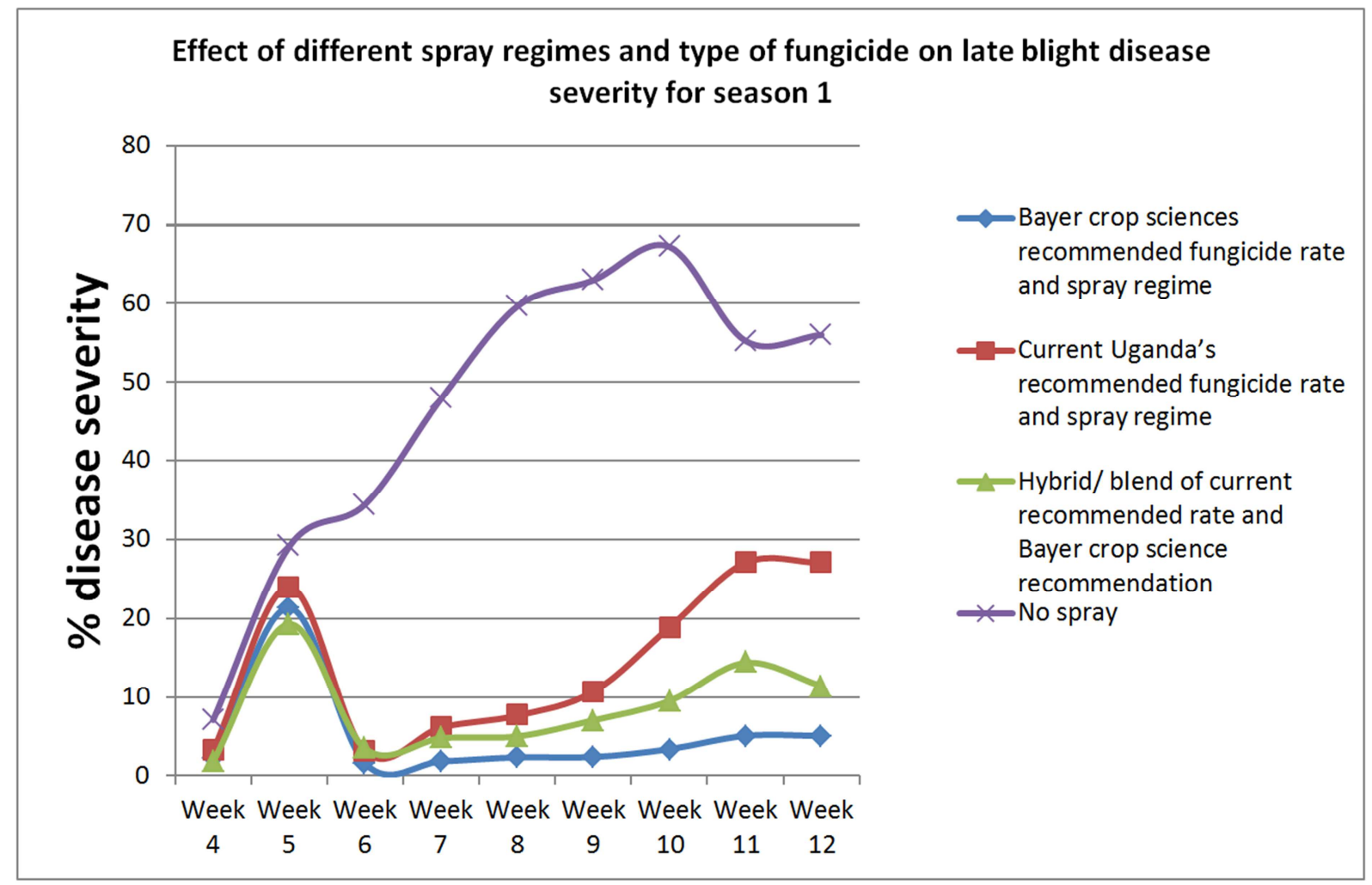

Figure 1. Effect of different spray regimes and type of fungicide on late blight disease severity for season 1.

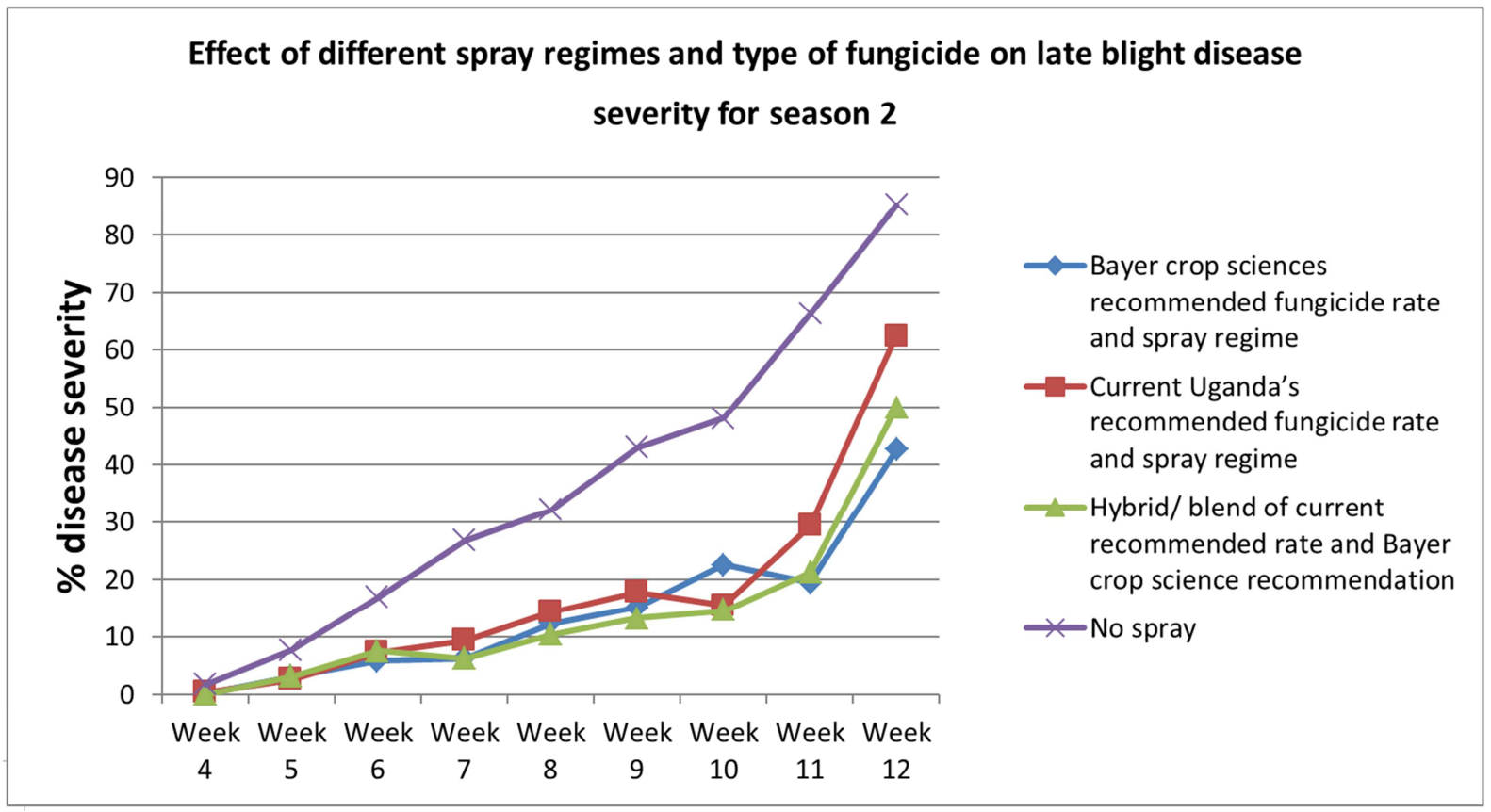

Figure 2. Effect of different spray regimes and type of fungicide on late blight disease severity for season 2.

Table 2. Effect of different spray regimes on a mount of late blight disease (Area under disease progress Curve (AUDPC) on four potato varieties.

\begin{tabular}{|c|c|c|c|c|c|}
\hline \multirow{2}{*}{ Spray regime } & \multirow{2}{*}{ Variety } & \multicolumn{3}{|l|}{ Season 1} & \multirow{2}{*}{ Season 1 mean } \\
\hline & & Buginyanya & Kachwekano & Kalegyere & \\
\hline \multirow{5}{*}{$\begin{array}{l}\text { Bayer Crop Sciences } \\
\text { recommended spray regime, }\end{array}$} & & 337.9 & 214.5 & 504.0 & 352.1 \\
\hline & Markies & 213.5 & 177.1 & 491.4 & 294.0 \\
\hline & Victoria & 638.4 & 338.1 & 499.8 & 492.1 \\
\hline & Sagitta & 212.1 & 195.0 & 504.0 & 303.7 \\
\hline & El Mundo & 287.7 & 147.7 & 520.8 & 318.7 \\
\hline Current Uganda's & & 366.9 & 363.8 & 1697.3 & 849.7 \\
\hline
\end{tabular}




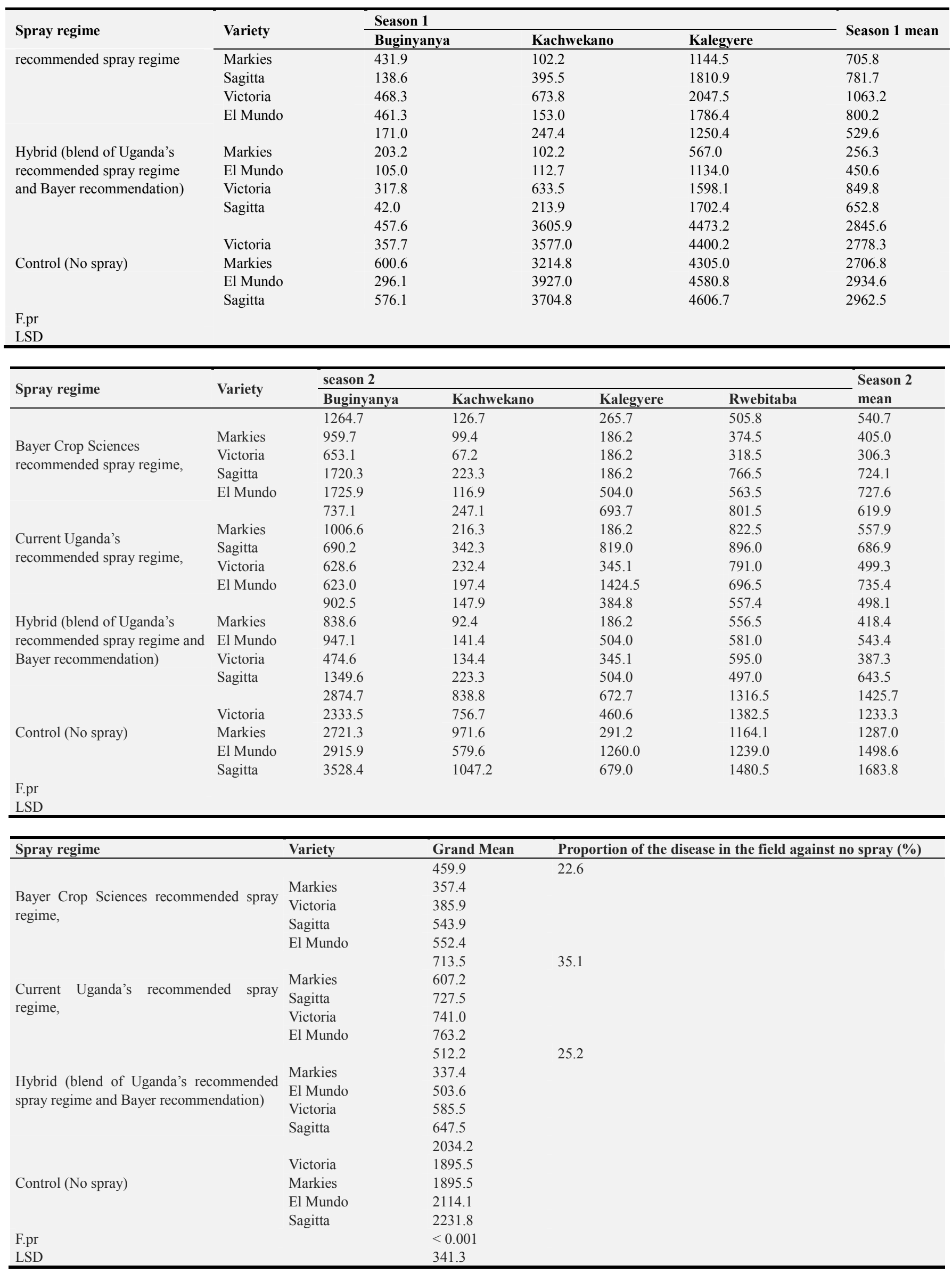


Table 3. Yield of the different potato varieties as influenced by different fungicide active ingredient and spray regimes.

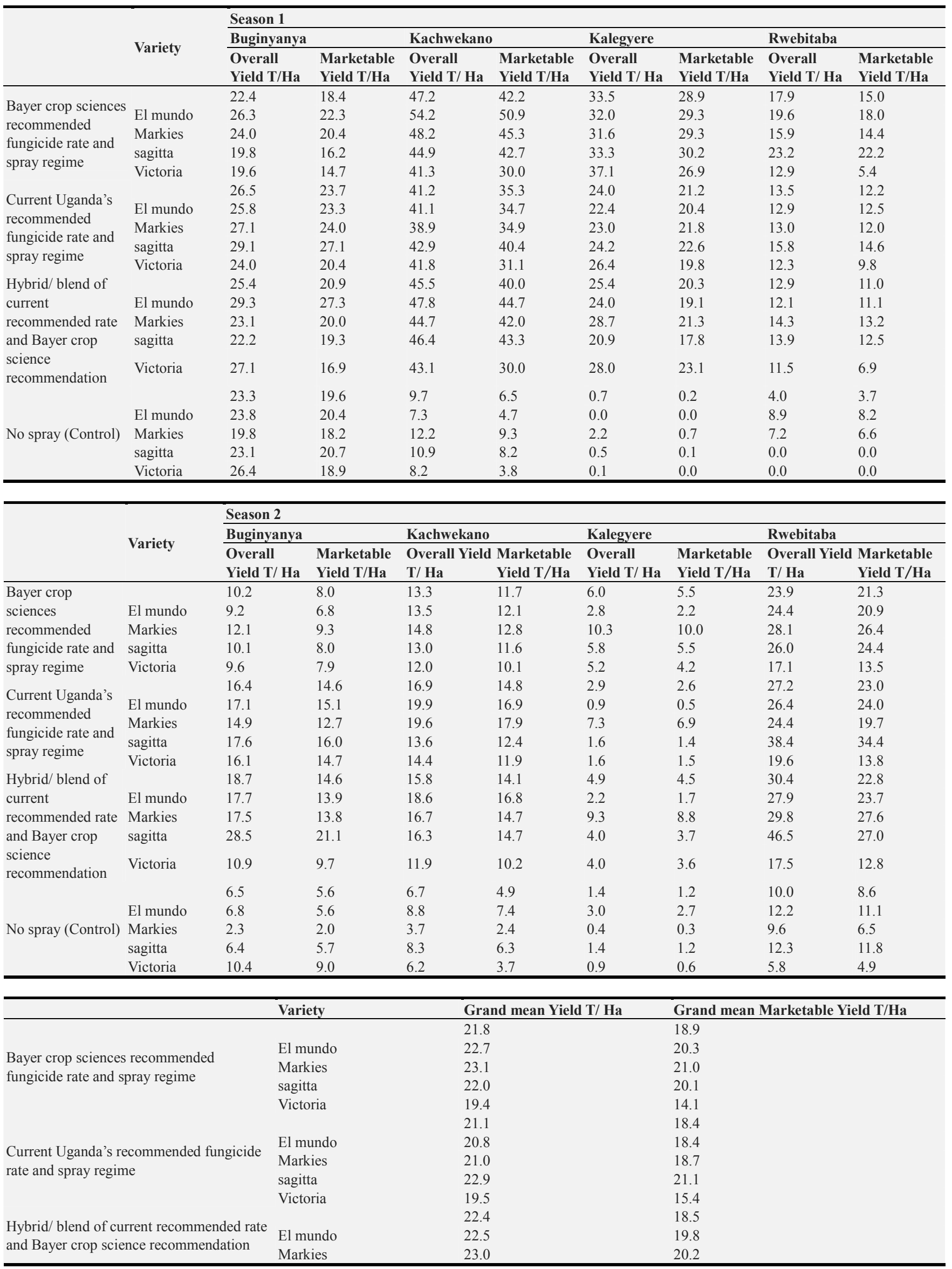




\begin{tabular}{llll}
\hline & Variety & Grand mean Yield T/ Ha & Grand mean Marketable Yield T/Ha \\
\hline & sagitta & 24.8 & 19.9 \\
& Victoria & 19.3 & 14.2 \\
& & 7.8 & 6.3 \\
No spray (Control) & El mundo & 8.9 & 7.5 \\
& Markies & 7.2 & 5.8 \\
& sagitta & 7.9 & 6.7 \\
& Victoria & 7.3 & 5.1 \\
\hline
\end{tabular}

\section{Conclusion}

The late blight disease pressure can effectively be managed by using a combination of different fungicide active ingredient and its application should follow the following regime; Application of $50 \mathrm{~g}$ of Mancozeb (Dithiocarbamate $800 \mathrm{~g} / \mathrm{kg}) / 15$ litres of water) in $1^{\text {st }}$ and $2^{\text {nd }}$ week after emergence followed by $30 \mathrm{ml}$ Consento (Fenamidone $6.7 \%$ $\mathrm{w} / \mathrm{w}+$ Propamacarb hydrochroride $93.6 \% \mathrm{w} / \mathrm{w}) / 15$ litres of water in the $3^{\text {rd }}$ week after emergence, then $50 \mathrm{~g}$ of Mancozeb (Dithiocarbamate $800 \mathrm{~g} / \mathrm{kg}$ ) $/ 15$ litres of water) during the $5^{\text {th }}$ week after emergence, followed by $27 \mathrm{ml}$ of Infinito (Propamacarb $(55.3 \% \mathrm{w} / \mathrm{w}+$ Fluopicollide $(5.53 \% \mathrm{w} / \mathrm{w}) / 15$ mls of water during $6^{\text {th }}$ week, followed by $50 \mathrm{~g}$ of Mancozeb (Dithiocarbamate $800 \mathrm{~g} / \mathrm{kg}$ ) $/ 15$ litres of water) in the $7^{\text {th }}$ weeks and last application to be done using $50 \mathrm{~g}$ of Agrolaxzyl (Metalaxyl $80 \mathrm{~g} / \mathrm{kg}+$ Mancozeb $640 \mathrm{~g} / \mathrm{kg}$ WP) $/ 15$ litres of water in the $8^{\text {th }}$ week or $9^{\text {th }}$ week. This regime would also reduces on likely chances of development of fungicide resistance by the late blight pathotype

\section{Acknowledgements}

We acknowledge the support from International Fertilizer Development Center (IFDC) for provision of funds to carry out this study. Also special thanks go to Bayer Crop Sciences for provision of fungicides that were used in this study.

\section{References}

[1] Brent, K. J., \& Hollomon, D. W. (1995). Fungicide resistance in crop pathogens: How can it be managed?. Brussels: GIFAP.

[2] Byarugaba, A. A., Prossy, N., \& Kashaija, I. N. (2013). Identification of potato clones of population $\mathrm{B} 3 \mathrm{C} 2$ with durable field resistance to late blight (Phytophthora infestans) and high yields in Uganda, 8 (23), 3055-3059. http://doi.org/10.5897/AJAR2013.6917.
[3] Campbell, C. L and Madden. V, 1990. Introduction to Potato disease Epidemiology. John Wiley and sons, New York. $532 \mathrm{pp}$.

[4] Forbes, G. A. (2012). Using host resistance to manage potato late blight with particular reference to developing countries. Potato Research, 55 (3-4), 205-216.

[5] Fry, W. E., Birch, P. R. J., Judelson, H. S., Grünwald, N. J., Danies, G., Everts, K. L.,... \& McGrath, M. T. (2015). Five reasons to consider Phytophthora infestans a reemerging pathogen. Phytopathology, 105 (7), 966-981.

[6] Gopal. J and B. E. Singh. 2003. Screening potatoes for resistance to late blight (Phytophthora infestans) under field conditions. Potato research 46 (2003/4) 47-56.

[7] Haverkort, A. J., Boonekamp, P. M., Hutten, R., Jacobsen, E., Lotz, L. A. P., Kessel, G. J. T. \& Van der Vossen, E. A. G. (2008). Societal costs of late blight in potato and prospects of durable resistance through cisgenic modification. Potato Research, 51 (1), 47-57.

[8] Henfling, J. W. 1987. Late blight of potato, Phytophthora infestans Technical information bulletin 4. CIP, Lima, Peru.

[9] Kankwatsa, P., J. J. Hakiza, M. Olanya, H. M. Kidenamariam, and E. Adipala. "Efficacy of different fungicide spray schedules for control of potato late blight in Southwestern Uganda." Crop Protection 22, no. 3 (2003): 545-552.

[10] Landeo J. A and Forbes, G. A. 2006. Late Blight. Pages 279320 in: Handbook of Potato production, Improvement, and Postharvest Management. J. Gopal and K. S. M. P., eds. Haworth Press Inc., Binghamton, NY.

[11] Namanda, S., Olanya, O. M., Adipala, E., Hakiza, J. J., ElBedewy, R., Baghsari, A. S., \& Ewell, P. (2004). Fungicide application and host-resistance for potato late blight management: benefits assessment from on-farm studies in SW Uganda. Crop Protection, 23 (11), 1075-1083.

[12] Njoroge, A. W., Tusiime, G., Forbes, G. A., \& Yuen, J. E. (2015). Displacement of US - 1 clonal lineage by a new lineage of Phytophthora infestans on potato in Kenya and Uganda. Plant Pathology.

[13] Olson, B. D. (2000). Crop disease and yield loss. Biotic Stress and Yield Loss, 15. 